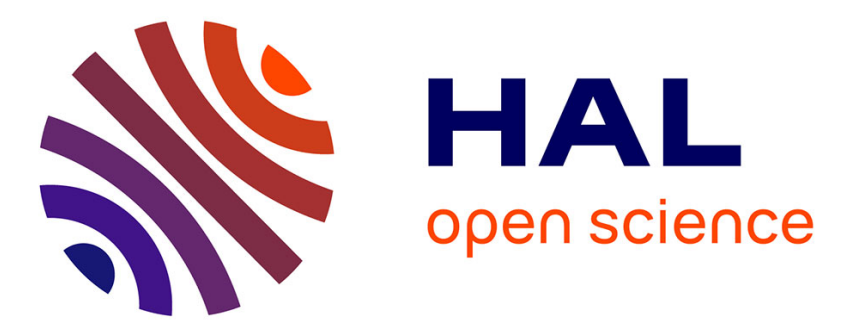

\title{
A hydrostatic high-pressure cell for neutron scattering experiments at room temperature
}

\author{
R. Millet, R.J. Papoular
}

\section{To cite this version:}

R. Millet, R.J. Papoular. A hydrostatic high-pressure cell for neutron scattering experiments at room temperature. Revue de Physique Appliquée, 1984, 19 (9), pp.827-832. 10.1051/rphysap:01984001909082700 . jpa-00245272

\section{HAL Id: jpa-00245272 https://hal.science/jpa-00245272}

Submitted on 1 Jan 1984

HAL is a multi-disciplinary open access archive for the deposit and dissemination of scientific research documents, whether they are published or not. The documents may come from teaching and research institutions in France or abroad, or from public or private research centers.
L'archive ouverte pluridisciplinaire HAL, est destinée au dépôt et à la diffusion de documents scientifiques de niveau recherche, publiés ou non, émanant des établissements d'enseignement et de recherche français ou étrangers, des laboratoires publics ou privés. 


\title{
A hydrostatic high-pressure cell for neutron scattering experiments at room temperature
}

\author{
R. Millet and R. J. Papoular \\ Léon Brillouin Laboratory, CEN-Saclay, 91191 Gif sur Yvette Cedex, France
}

\begin{abstract}
Résumé. - Les effets d'absorption des neutrons doivent être minimisés lors de la conception d'une cellule haute pression utilisable pour des études de diffusion. Le choix des constituants de base pour la réalisation d'une telle cellule s'en trouve très restreint et la forme des éléments constitutifs doit être modifiée par rapport à celle des cellules haute pression utilisées avec d'autres techniques expérimentales. Il en résulte que la pression hydrostatique maximale accessible est considérablement diminuée (en dessous de $25 \mathrm{kbar}$; celle-ci dépend aussi de l'échantillon). Une caractéristique originale de notre cellule réside dans la réalisation d'un passage électrique étanche permettant l'utilisation d'une jauge résistive de manganin et donnant la lecture en continu de la pression hydrostatique (avec ou sans les neutrons).
\end{abstract}

\begin{abstract}
The design of a high-pressure cell to be used in scattering experiments must ensure a low absorption of the neutrons by the cell. This, in turn, restricts the choice of the raw materials of which the cell can be made and calls for changes in the shape of the constitutive elements with respect to standard designs used in high-pressure work in other fields. As a result, the maximum attainable hydrostatic pressure is considerably lowered (to under $25 \mathrm{kbar}$; it also depends upon the sample). One original feature of our work is a highly reliable fluid tight electrical passage which allows the use of a manganin gauge for continuous monitoring of the inner pressure (with or without neutrons).
\end{abstract}

\section{Introduction.}

The present paper describes an hydrostatic highpressure device of the piston-in-cylinder type using deuterated propanol-2 alcohol as the liquid transmitting pressure and unloaded teflon as the ductile material of which the high-pressure (HP) vessel is made. The overall design is not new and the reader is referred to chapter 2 of reference [1] for basic principles. Ours was devised by Dr. D. Debray.

But the salient features of our design are :

- First, to put into the pressure transmitting liquid a secondary gauge that is easily calibrated, reproducible, portable and accurate, namely a manganin resistance, which has a small temperature coefficient of resistivity [2].

For this purpose, we developed an electrical feedthrough allowing copper wires to run out of the pressure vessel without permitting any leak to occur (Fig. 1a, b, c).

- Second, to work out a proper environment of the pressure vessel such as to prevent any spurious flow of the teflon into the cracks which inevitably occur in the outer conical alumina cylinder.

The next sections will deal respectively with the point mentioned above, the way the HP cell is operated during an experiment, what information can be gained and with what limitations, and finally possible extensions of our work will be sketched out.

\section{Experimental.}

2.1 The SETting-uP OF THE HP NEUTRON CELL. The high-pressure vessel consists of an electrical passage (shown in Fig. 1a on an enlarged scale and also at the bottom of Fig. 2a), a teflon cylinder and a teflon top equipped with an indium seal. The two latter parts are distinct in order to avoid bursting of the teflon assembly above 20 kbar.

The vessel is inserted into the alumina conical cylinder, which has been thermally shrunk and fitted into the maraging steel piece (Fig. 2b) beforehand. 


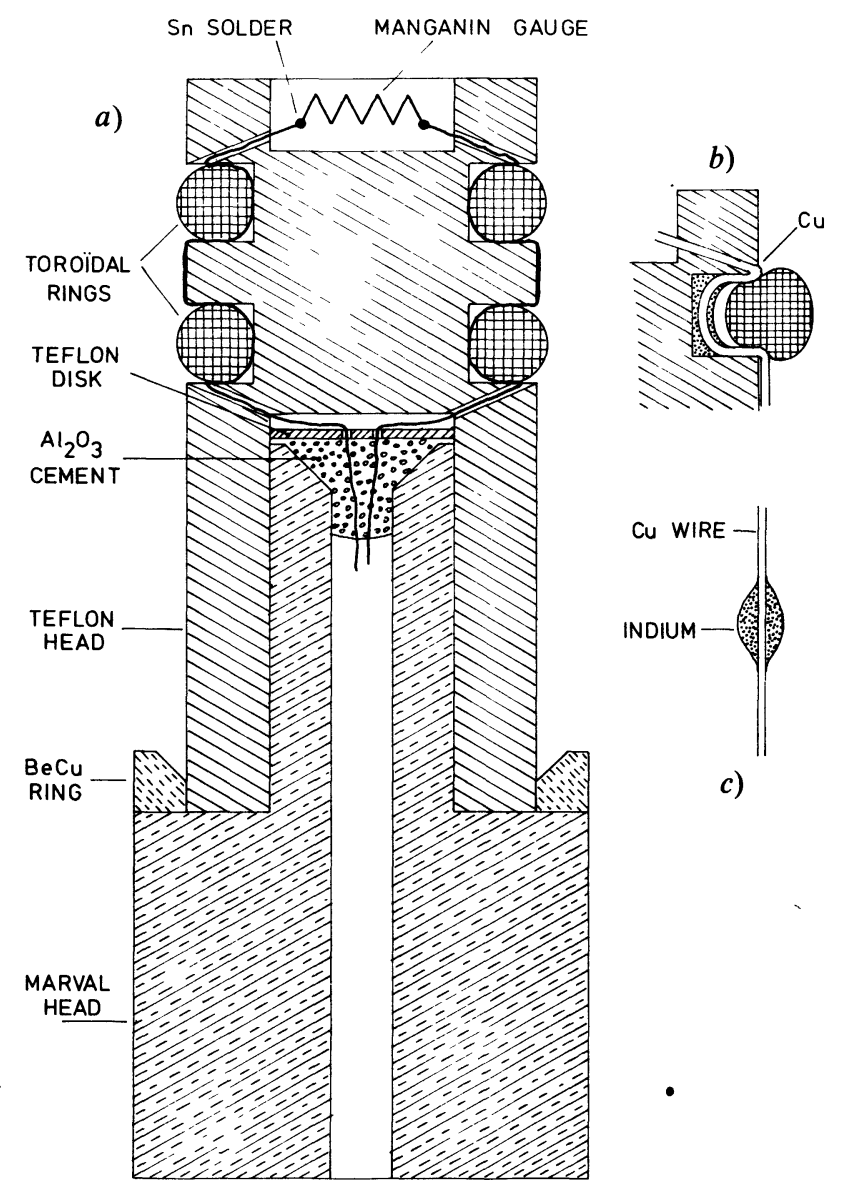

Fig. 1a. - Enlarged view of the electrical passage showing the manganin gauge and the copper wire arrangement. (Note the presence of the thin teflon disk on top of the alumina cement).

Fig. 1b, c. - Nesting of the copper wires between the teflon part of the passage and the rubber o-ring. The indium drop (darkened area) forbids any possible leak of alcohol along the copper wires outside the teflon vessel.

Formulas for such a multilayer cylindrical arrangement can be found in [3], yielding coarse estimates for the different stresses in the cell assembly.

The lower screw (Fig. 2b) is then tightened, while its inner free part is held firmly. The purpose of this latter device, which is made of steel and has a little hole drilled in it along its axis, is to let the electrical copper wires out of the cell safely and to leave the electrical passage unaffected by the tightening and the rotation of the screw.

Before tightening the upper screw, a small tungsten carbide (WC) piston is introduced on top of the teflon part of the HP vessel, inside the alumina cylinder. The upper screw with its two inner cylinders (made of steel and tungsten-carbide respectively) is then tightened enough to prevent leaks of alcohol from occurring.

The $\mathrm{BeCu}$ cylinder (used to coat the teflon tube), disk and ring (shown in Figs. 2a and la respectively) prevent the teflon flow from the HP vessel does

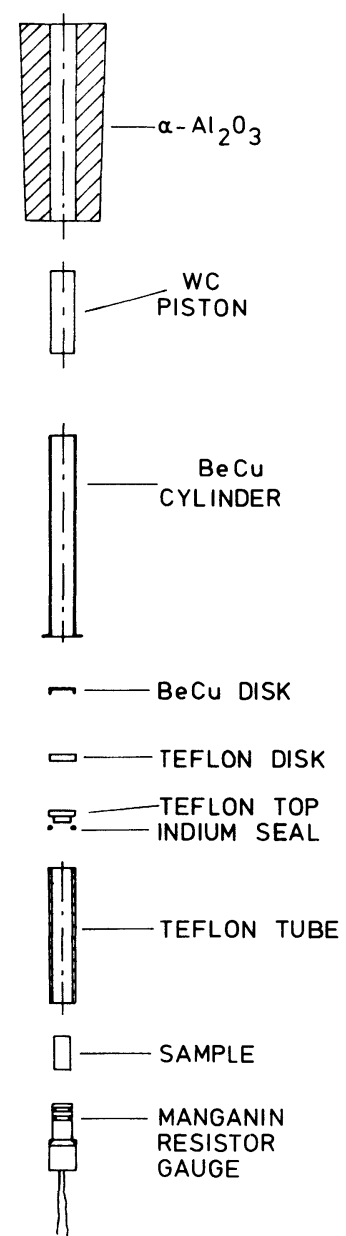

a)
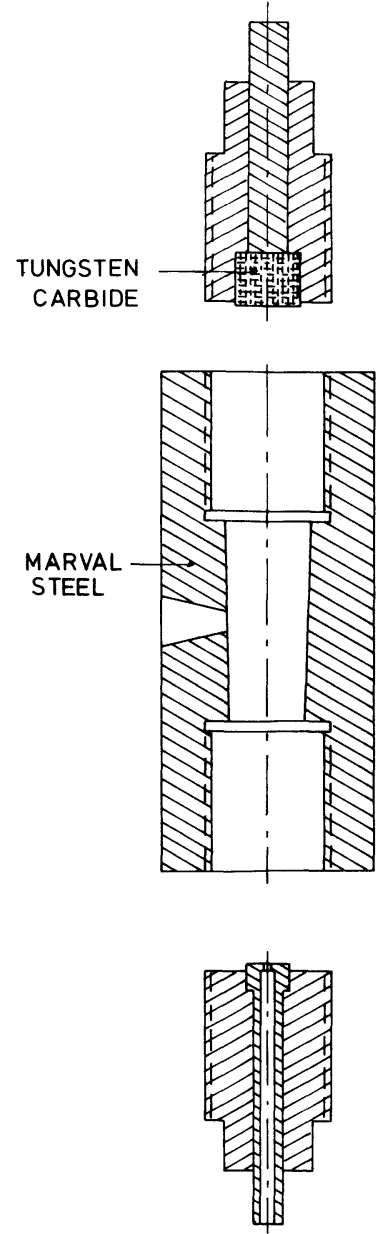

b)
Fig. 2a. - Exploded view of the teflon vessel (containing the transmitting pressure fluid and the sample) with its surrounding elements inside the alumina piece.

Fig. 2b. - The marval steel main frame and its two retaining hollow screws. (Note the steel and the tungsten carbide small cylinders inside the upper screw).

not occur outwards, especially into the cracks of the alumina cylinder which occur inevitably.

2.2 The manganin Resistance gauge. - It consists of a coil of a specially enamelled manganin wire (Table I) approximately $25 \mathrm{~cm}$ long. It is packed as carefully and as loosely as possible at the top of the passage (Fig. 1a) and it is totally immersed in the alcohol when the HP vessel is filled up. To get rid of possible strains occurring during the packing into the passage, the following seasoning has to be performed : first, the whole passage is annealed at $120^{\circ} \mathrm{C}$ for 5 hours, then it is quenched to liquid nitrogen temperature and then annealed again at $120^{\circ} \mathrm{C}$ for 22 hours (Private communication from D. L. Decker).

The overall resistance of the gauge is of the order of $130 \Omega$ and the heating treatment lowers its original value by about $1 \Omega$.

The calibration of the resistance $R$ as a function 
Table I.

\begin{tabular}{|l|l|l|l|}
\hline \multicolumn{1}{|c|}{ Name of constituent } & \multicolumn{1}{|c|}{ Special features } & \multicolumn{1}{|c|}{$\begin{array}{l}\text { Commercial } \\
\text { Designation }\end{array}$} & \multicolumn{1}{|c|}{$\begin{array}{c}\text { Manufacturing } \\
\text { Company }\end{array}$} \\
\hline $\begin{array}{l}\text { Marval (Maraging) Steel } \\
\text { Alumina } \mathrm{Al}_{2} \mathrm{O}_{3}\end{array}$ & N18K9D5T $\phi 6$ & $18 \mathrm{H}$ & \multicolumn{1}{c}{ Aubert et Duval } \\
$\mathrm{BeCu}$ & $\mathrm{Be} \sim 2 \%$ & TS271 & L.L.C. \\
Teflon $\left(\mathrm{C}_{2} \mathrm{~F}_{4}\right)_{\mathrm{n}}$ & Density $: 2.3$ & $33-25$ & $\begin{array}{l}\text { Pirep } \\
\text { PTFE }\end{array}$ \\
Manganin & $\varnothing: 0.03 \mathrm{~mm}$ enamelled & & Ballofet \\
Liquid Transmitting Pres- & $R: 608 \Omega / \mathrm{m}$ & & \\
sure Propanol-2 & $99 \%$ deuterated & Propanol-2 D8 & CEA/SMM \\
\hline
\end{tabular}

of pressure is given in [2]. For the range of pressures attainable by our cell, the following quadratic formula is used :

$$
P=A\left(\Delta R / R_{0}\right)+B\left(\Delta R / R_{0}\right)^{2}
$$

where $P$ is expressed in $\mathrm{kbar}, A=419.774 \mathrm{kbar}$ and $B=258.509 \mathrm{kbar}$ (a change of resistance of $1 \Omega$ corresponds roughly to $3 \mathrm{kbar}$ ). Reference [2] also gives a temperature coefficient of resistance for the manganin of $3.8 \times 10^{-6} /{ }^{\circ} \mathrm{C}$.

The precision of a pressure measurement is within 200 bar, taking into account the possible flow of the constituents and temperature fluctuations during the whole experiment which may last up to 3-4 days. The alternative way of estimating pressure, using Decker's $\mathrm{NaCl}$ equation of state [4] does not allow for continuous monitoring. It is somewhat less accurate and demands that a $\mathrm{NaCl}$ sample be also present in the HP vessel and the neutron beam.

2.3 The Electrical PASSAGe. - There are two main difficulties occurring under high-pressures :

(i) The resistance gauge or the copper leads may break or make a short-circuit.

(ii) The alcohol may leak out of the HP vessel, for instance by corroding the varnish of the copper leads and leaking along them.

To prevent (i) from occurring, two steps are taken : first the manganin is placed in a little hole dug into the teflon top of the passage, second the positions of the copper wires are stabilized at the exit of the passage by putting both a small teflon disk and some $\mathrm{Al}_{2} \mathrm{O}_{3}$ cement (Fig. 1a).

As for (ii), a malleable drop of indium is deposited on each copper lead, which will result in a tight seal against possible alcohol leaks when pressed upon by the rubber o-ring (Fig. 1b, c).

2.4 The PRESSURE TRANSMITTING FlUID (PTF). Near room temperature, liquid hydrocarbons (deuterated for neutron scattering purposes) are the most widely used PTF's. In our case, fluorinert and the deuterated ethanol/methanol mixture were discarded because the former becomes solid above $15 \mathrm{kbar}$ and the latter is too compressible.

The deuterated propanol-2 was chosen instead and enabled us to reach the 25 kbar range of hydrostatic pressures even with porous samples (powders).

(A very comprehensive list of compressibility data is given in [5] p. 128-130.)

2.5 THE SAMPLE. - It consists of a cylinder the diameter and height of which are $5 \mathrm{~mm}$ and $10 \mathrm{~mm}$ respectively. Only polycrystalline materials were used so far [6] but in principle a cylinder-shaped monocrystal could also be investigated provided that its axis be a known crystallographic direction. The teflon tube of the HP vessel has an inner diameter of $5.6 \mathrm{~mm}$, an outer one of $7.4 \mathrm{~mm}$ and a height of $41 \mathrm{~mm}$.

The first dimension allows the sample to fit easily in the cell and the last one, derived after many experiments, corresponds to the volume of the sample being almost equal to the required volume of alcohol at ambient pressure to fill up the HP vessel.

In case a powder is used, it has to be wrapped in a $0.02 \mathrm{~mm}$ thick aluminium foil and shaped as a cylinder of the above size.

\section{Operating the cell (Fig. 3 and Fig. 4).}

A standard compressor from the Basset-Bretagne Company is used to generate a hydrostatic pressure up to a few hundred bars which is subsequently used to activate a hydraulic press that will drive the HP neutron cell piston $(G)$. The pressure is transmitted to the HP vessel through a few steel/tungsten carbide pistons. The amplifying factor, given by the ratio of the inner press area to the area of the WC piston section acting on the HP vessel, is 358 .

The displacement $d$ of the piston $\mathrm{G}$, the primary pressure $P P$ of the hydraulic press and the resistance $R$ of the manganin gauge as well as possible temperature measurements are fed into the $X Y$-table and the computer.

When the HP neutron cell is set to the desired pres- 


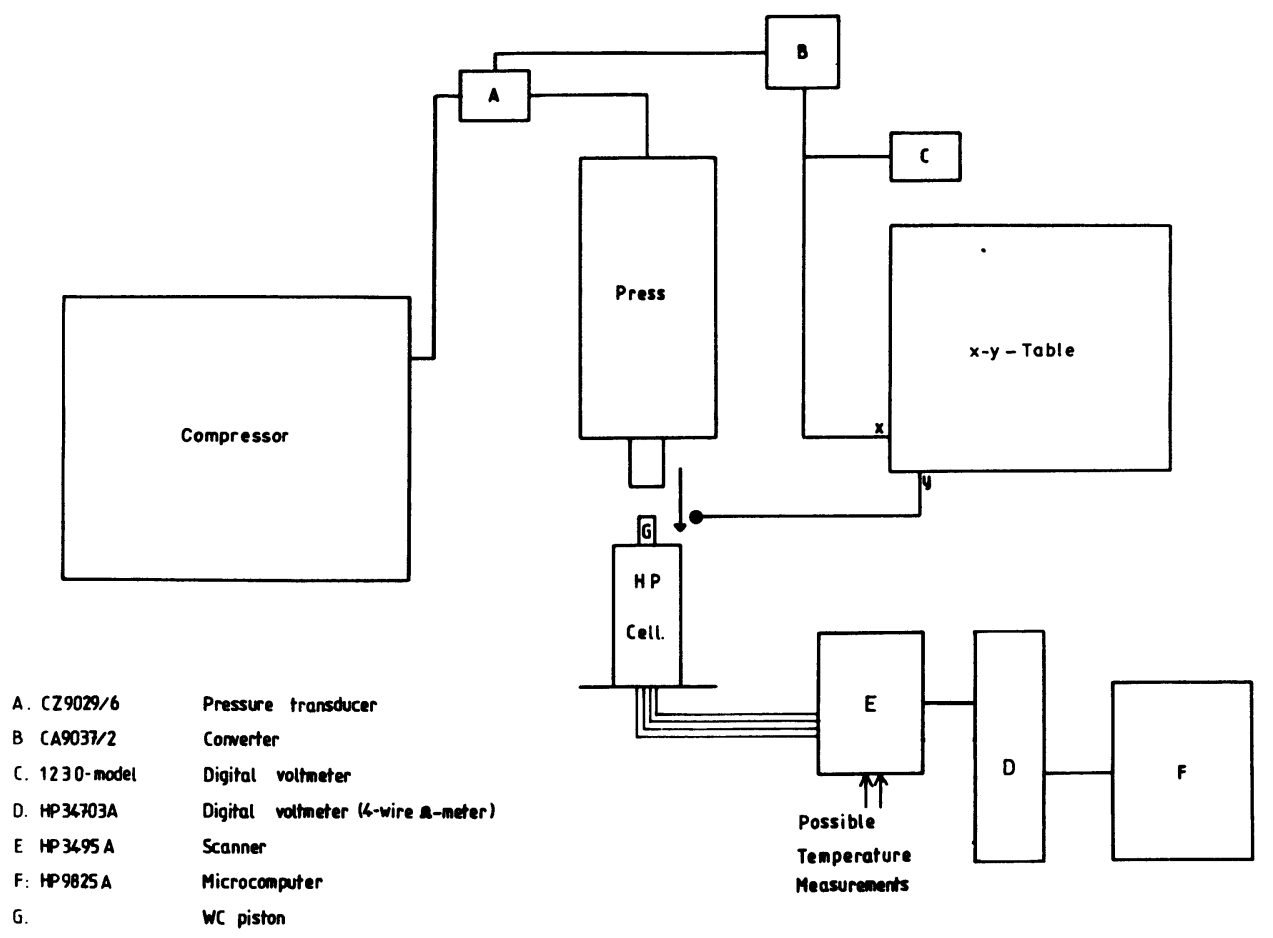

Fig. 3. - General layout of the experiment (The WC piston can alternatively be made of steel).

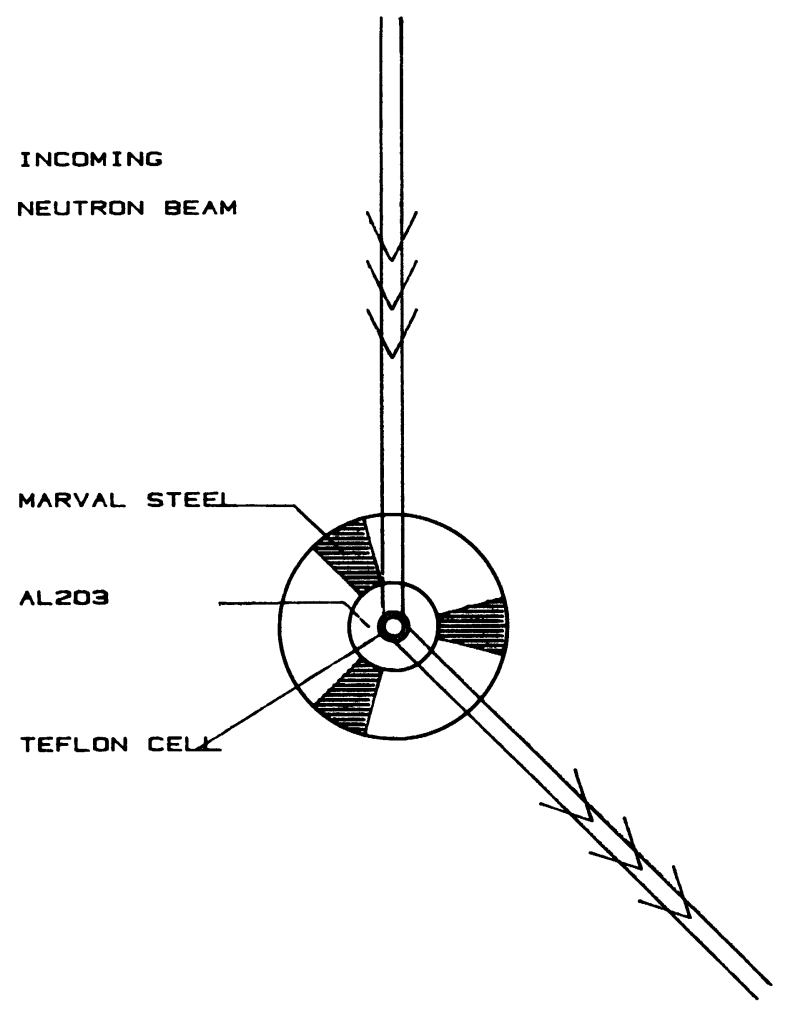

OUTGOING

NEUTRON BEAM

\section{SCATTERING PLANE}

Fig. 4. - View from above of the scattering plane showing the three 90 degree windows for the neutron beams in and out the marval steel piece. sure, the upper marval screw (Fig. 2b) is strongly tightened before the load of the press is released and one waits for $R$ to be stabilized to within a few $\mathrm{m} \Omega$ before starting the neutron measurements.

\section{What other information can be gained ?}

One may wonder if compressibility informations (as well as phase transition hints) could be obtained from $d v s$. $P$ or $d v s$. $P P$ curves. The subject is under current investigation and is not easy due to our ignorance of friction stresses exerted on the $H P$ vessel during the experiments. These curves are not readily reproducible but it has been observed repeatedly that up to 12 kbars : (i) $P$ is a linear function of $P P$ with the right ratio (358) with reasonable accuracy; (ii) $d$ is a cubic function of $P$ and that an extrapolation to $P \rightarrow 0$ gives a reasonable estimate of the true displacement of the piston.

Remember that when the upper marval screw is tightened to prevent leakage, the teflon tube is compressed by a millimeter or so. This effect is not negligible for compressibility estimates.

\section{An important remark :}

The maximum attainable hydrostatic pressure does depend upon the compressibility of the sample under study. It is limited by the maximum uniaxial stress teflon can sustain. The higher the compressibility of the mixture (sample + alcohol), the more quickly this maximal stress is reached.

In particular, if no sample is set in the HP vessel, even the $15 \mathrm{kbar}$ range will not be reached. If teflon is now chosen as the sample, a limit will be reached 
at about $20 \mathrm{kbar}$. A blank run is therefore not easy to define.

\section{Limitations.}

Various limitations determine the range of usable hydrostatic pressures ( $2 \mathrm{kbar}-25 \mathrm{kbar}$ ).

The lower limitation is due to the fact that the teflon vessel, containing the sample and the alcohol, has to be pressed with a minimal strength against the passage to prevent leaks.

The higher limitation $(\leqslant 25 \mathrm{kbar})$ results from the possible breaking of the alumina piece and the viscosity of the propanol-2 which will generate anisotropic stresses both onto the sample and the manganin resistance. That the latter does not occur can be confirmed by measuring the manganin gauge when the pressure is relieved at the end of the experiment. The original value should be recovered to within $50 \mathrm{~m} \Omega$.

In diffraction experiments, the usable range can be deduced from the neutron patterns shown in figure 5 and figure $6 \mathrm{a}, \mathrm{b}, \mathrm{c}(\lambda=2.45 \AA)$. Much care has to be taken in the $1.33 \AA^{-1}-2.5 \AA^{-1}$ range in particular, where the background is seen to vary quite noticeably with pressure.

\section{Possible developments.}

- In order to use our cell with polarized neutrons, the maraging steel must be replaced (by a $\mathrm{BeCu}$ alloy) as well as our pistons for which $\mathrm{BeCu}$ and cemented WC are possible candidates. Such a cell is currently under study and a 10-15 kbar upper limit is expected due to $\mathrm{BeCu}$ flow. The main expected difficulty is the weakness of the neutron flux.

- As can be seen from figure 4, our cell does not allow for S.A.N.S. (Small Angle Neutron Scattering) experiments. A simple change in the steel piece geometry (replacing the three $90^{\circ}$ windows by four $65^{\circ}$ windows symmetrically arranged about the vertical axis) is suggested. The small angle scattering signal from a «blank " experiment should then be studied

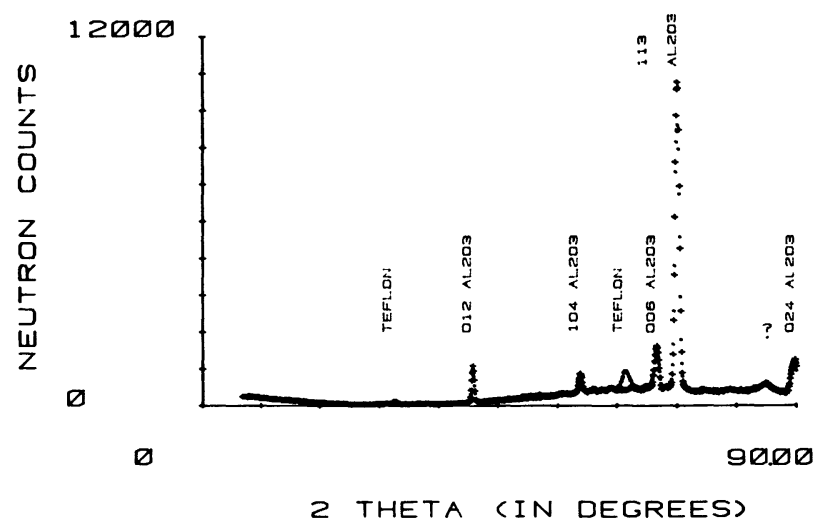

Fig. 5. - Overall neutron diffraction pattern at $2 \mathrm{kbar}(+)$ and at $15 \mathrm{kbar}($.$) obtained with an incident neutron wave-$ length of $2.45 \AA$.
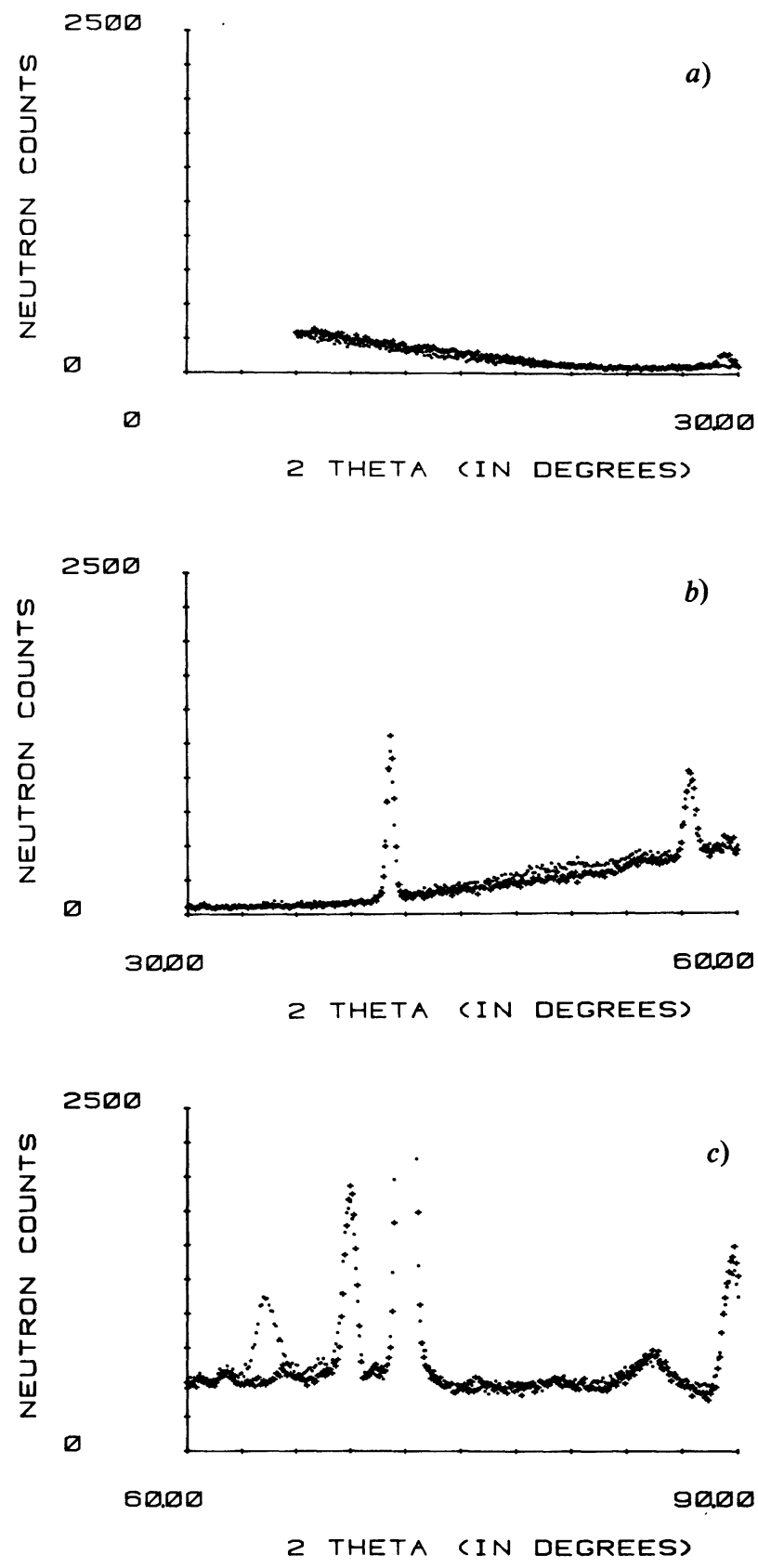

Figs. 6a, b, c. - Same run as figure 5 but shown with an enlarged scale. Notice pressure-induced teflon effects.

at each pressure of interest to permit an estimate of the background intensity shift which is of primary importance for S.A.N.S. experiments.

- Lastly, low temperature studies are by no means obvious since the liquid which transmits pressure becomes solid as temperature is lowered, and possible anisotropic stresses are expected. Besides, a calibration law for the manganin (Resistance vs. Pressure and Temperature) remains to be determined, provided that reproducible measurements can be achieved. Note finally that our cell is compatible with the standard cryostats available at the Laue Langevin Institute (I.L.L., Grenoble). 


\section{Acknowledgments.}

The authors wish to thank Professor D. L. Decker (BYU/USA) for helping them to design the high- pressure cell and to operate it, Dr. D. Debray for valuable information, Dr. Y. Allain for letting them use his neutron diffractometer and C. Menetrier for helping them with some of the drawings.

\section{References}

[1] Stewart, J. W., The World of High Pressure (Van Nostrand) 1967.

[2] Zeto, R. J., Vanfleet, H. B., J. Appl. Phys. 40 (1969) 2227.

[3] Faupel, J. H. in Pressure Vessel Engineering Technology, R. W. Nichols, Ed. (Applied Science Publishers) 1971, Chapter 8, p. 402.

[4] Decker, D. L., J. Appl. Phys. 42 (1971) 3239.
[5] Bridgman, P. W., The Physics of High-Pressure (Dover) 1970.

[6] See for instance : Debray, D., Millet, R., JÉrome, D., Parisic, S., Giral, L., Fabre, J. H., J. Physique Lett. 38 (1977) L-227.

Decker, D. L., Petersen, S., Debray, D., Lambert, M., Phys. Rev. B 19 (1979) 3552. 